\section{Cytotoxic Effect of Thymus caramanicus Jalas on Human Oral Epidermoid Carcinoma KB Cells}

\author{
Reza Fekrazad ${ }^{1,2}$, Mehrad Afzali3,4, Hamzeh Pasban-Aliabadi ${ }^{5}$, Saeed Esmaeili- \\ Mahani $^{6,7}$, Maryam Aminizadeh ${ }^{8}$, Ali Mostafavi ${ }^{9}$
}

\begin{abstract}
Identifying new chemotherapeutic agents with fewer side effects is a major concern for scientists today. Thymus caramanicus Jalas (Lamiaceae family) is one of the species of Thymus that grows wild in different regions of Iran. Traditionally, leaves of this plant are used in the treatment of diabetes, arthritis and cancer. Here was investigated the cytotoxic property of Thymus caramanicus essential oil and extract in human oral epidermoid carcinoma KB cells. Cell viability was measured by MTT and neutral red assays. The cells were exposed to different concentrations of essential oil $(0.05-1 \mu \mathrm{L} / \mathrm{mL})$ and extract $(25-150 \mu \mathrm{g} / \mathrm{mL})$ for $24 \mathrm{~h}$. Doxorubicin was used as anticancer control drug. The data showed that the essential oil (IC50 $=0.44 \mu \mathrm{L} / \mathrm{mL})$ and extract $($ IC $50=105 \mu \mathrm{g} / \mathrm{mL})$ induce potent cytotoxic property. Surprisingly, cytotoxic effects of essential oil and extract of this plant on KB cancer cells were greater than those on normal gingival HGF1-PI1 cell line. In addition, Thymus caramanicus could potentiate the effect of doxorubicin in subeffective concentrations. The results of the present study indicate that essential oils and extracts of Thymus caramanicus have potential anti-proliferative property on KB cells and can be used as pharmaceutical case study for oral cancer treatments.
\end{abstract}

Key Words: Thymus caramanicus, cytotoxic effect, oral epidermoid carcinoma, KB cells.
'Department of Periodontology, Laser Research Center in Medical Sciences (LRCMS), AJA University of Medical Sciences, Tehran, Iran ${ }^{2}$ International Network for Photo Medicine and Photo Dynamic Therapy (INPMPDT), Universal Scientific Education and Research Network (USERN), Tehran, Iran

${ }^{3}$ Persian Gulf Oral and Dental

Disease Research Center,

Hormozgan University of Medical Sciences, Bandar Abbas, Iran ${ }^{4}$ Laser research center in medical

Sciences, AJA University of

Medical Sciences, Tehran, Iran

${ }^{5}$ Exercise Physiology Research Center, Baqiyatallah University of Medical Science, Tehran, Iran

${ }^{6}$ Laboratory of Molecular

Neuroscience, Kerman Neuroscience Research Center, Kerman University of Medical Sciences, Kerman, Iran ${ }^{7}$ Department of Biology, Faculty of Sciences, Shahid Bahonar University of Kerman, Kerman, Iran ${ }^{8}$ Department of Biotechnology, Shiraz University, Shiraz, Iran ${ }^{8}$ Department of Chemistry, Faculty of Sciences, Shahid Bahonar University of Kerman, Kerman, Iran

Correspondence: S. EsmaeiliMahani, Department of Biology, Faculty of Sciences, Shahid Bahonar University of Kerman, Kerman, Iran. P.O.Box: 76135-133. Tel: +98-343322-2032. e-mails: semahani@ yahoo.com, semahani@uk.ac.ir.

\section{Introduction}

Oral cancer is one of the most common malignancies in the world (1). It is characterized by a high degree of local invasiveness and a high rate of metastases to cervical lymph nodes. The migration of oral squamous cell carcinoma (SCC) into maxillary and mandibular bones is a common clinical problem (2).

The development of resistance to multiple drugs is a common clinical problem in the treatment of various cancers and many current therapeutic procedures have shown multiple side effects. In addition, common cytotoxic therapies primarily target rapidly dividing cells including malignant cells as well as certain normal cells, leading to significant morbidity and limited clinical benefits for troubled patients. Therefore, improving anticancer therapies that effectively and specifically target tumor cells while minimizing the toxic side effects on physiologically proliferating cells is strongly required (3). Increasing attention has been paid to naturally acquired compounds as new candidates (4). The renewed interest in natural substances, rather than in synthetic agents focused attention on plants used as food or spices, which are a rich source of bio-nutrients or bio-active phytochemical compounds and more detailed studies are needed to establish their safety (5).

The family of Thymus genus (Lamiaceae family) is among the most popular plants worldwide, commonly used as herbal teas, flavoring agents (condiment and spice), aromatic and medicinal plants (6). Furthermore, the essential oil and extract of different Thymus species are widely used in pharmaceutical, cosmetic and perfume industry, as well as for flavoring and preservation of several food products (7). Thymus caramanicus Jalas (Lamiaceae family) is one of the 400 species of Thymus that grows in the wild in different regions of Iran. In the Iranian folk medicine, leaves of this plant are used in the treatment of rheumatism, skin disorders and as an antibacterial agent (8). The beneficial health properties of thymol and carvacrol as main components of Thymus caramanicus have encouraged the authors to look into its anticancer activity. 
To the best of our knowledge, there are no available reports on the anticancer activity of Thymus caramanicus on KB cells. Therefore, the present study attempts to explore the potential anticancer activity of this plant on a human oral epidermoid carcinoma cell line.

\section{Material and Methods}

\section{Materials}

Cell culture reagents, penicillin-streptomycin solution, trypsin EDTA (Ethylene Diamine Tetra Acetic acid), fetal bovine serum (FBS) and heat-inactivated horse serum (HS) were obtained from Biosera Co. (East Sussex, UK). Culture flasks, plates and dishes were acquired from SPL Lifesciences Inc. (Gyeonggi-Do, South Korea). 3-[4,5-dimethyl-2thiazolyl]-2,5-diphenyl-2-tetrazolium bromide (MTT), neutral red and doxorubicin were purchased from Sigma (St. Louis, MI, USA).

\section{Plant Material and Preparation of Its Extract and Essential Oil}

The aerial parts of Thymus caramanicus were collected from Hezar Mountain (Kerman province, Southern Iran) at the flowering stage in June 2011. The plant materials were identified by Dr. Seyed Mansour Mirtadjadini (Department of Biology, Shahid Bahonar University of Kerman). The voucher specimens were also deposited at the Herbarium (reference number 1492) of the Shahid Bahonar University of Kerman (Kerman, Iran).

The air-dried leaves $(200 \mathrm{~g})$ of Thymus caramanicus were ground into fine powder, and then the ground powder was extracted with $1.5 \mathrm{~L}$ of ethanol and water mixture solvent (80:20) three times. The collective hydro-ethanolic extract was filtered through a filter membrane. After filtration process, the crude extract was completely dried with sodium sulphate. The solvent of extract was evaporated in rotary evaporator. The extract was weighted and dissolved in PBS buffer and used freshly.

For preparation of essential oils, $100 \mathrm{~g}$ of dried aerial parts of the plants in reproductive stage were hydrodistilled for $3.5 \mathrm{~h}$ using a Clevenger-type apparatus to produce the pale yellow oil in a $2.67 \% \mathrm{w} / \mathrm{w}$ yield. The oil was dried over anhydrous sodium sulfate and stored in sealed vials at low temperature before analysis. Gas chromatography-mass spectroscopy (GC-MS) analysis was done on a Hewlett-Packard 5973 connected with a mass detector HP6890 using a DB-1 column (55 $\mathrm{m} \times 0.25$ $\mathrm{mm}$, film thickness $0.25 \mu \mathrm{m}$ ). The experimental conditions were as follows: oven temperature programmed from 40 ${ }^{\circ} \mathrm{C}$ (1 min) to $250{ }^{\circ} \mathrm{C}\left(30 \mathrm{~min}\right.$ ) at $3{ }^{\circ} \mathrm{C} / \mathrm{min}$ (for both GCFID and GC/MS); injector and detector temperature; 320 ${ }^{\circ} \mathrm{C}$ and $310{ }^{\circ} \mathrm{C}$, respectively; the carrier gas $\mathrm{He}(99.999 \%)$ at a flow rate of $1 \mathrm{~mL} / \mathrm{min}$. The mass spectrometer was operated at $70 \mathrm{eV}$ with the mass range of $40-350 \mathrm{amu}$ and $1 \mathrm{~s}$ scan time.

\section{Cell Culture}

KB (oral carcinoma) and HGF1-PI1 (normal fibroblast of gingiva) cells were obtained from National Cell Bank of Iran (NCBI). Cells were grown with Dulbecco's modified Eagle medium (DMEM) supplemented with 10\% fetal bovine serum, penicillin $(100 \mathrm{U} / \mathrm{mL})$ and streptomycin $(100 \mathrm{~g} / \mathrm{mL})$. They were maintained at $37{ }^{\circ} \mathrm{C}$ in a $5 \% \mathrm{CO}_{2}$ atmosphere. Growth medium was changed three times a week. Cells were plated at the density of 5000 per well in a 96 micro plate well for the MTT and Neutral Red assay. All experiments were approved by the ethical committee of Kerman Neuroscience Research Center.

\section{Cell Viability Analysis \\ MTT Assay}

MTT Assay was performed by the reduction of 2-(4,5-dimethylthiazol-2-yl)-2,5-diphenyltetrazolium bromide (MT) to formazan. MTT was dissolved in PBS and added to the culture to a final concentration of $0.5 \mathrm{mg} / \mathrm{mL}$. After additional $2 \mathrm{~h}$ incubation at $37^{\circ} \mathrm{C}$, the media were carefully removed and $100 \mu \mathrm{L}$ DMSO was added to each well and the absorbance (OD) values were determined by spectrophotometry at $490 \mathrm{~nm}$ with microplate reader (Eliza MAT 2000, DRG Instruments GmbH, Marburg, Germany). Results were expressed as percentage of control.

\section{Neutral Red Assay}

The neutral red assay has been used extensively for in vitro assessment of cytotoxicity of infectious agents, food additives and pharmaceuticals. This assay is based on the incorporation of neutral red (3-amino-7dimethyl1-2-methylphenazine hydrochloride) into the lysosomes of viable cells after being incubated with test agents. Neutral red (4 mg/mL) was diluted 1:100 into medium and incubated overnight at $37^{\circ} \mathrm{C}$ and centrifuged before use. $200 \mu \mathrm{L}$ of prepared neutral red solution were added to each well and the cells were incubated at $37^{\circ} \mathrm{C}$ for $3 \mathrm{~h}$. After that, the cells were rapidly washed with a solution of $1 \%$ calcium chloride and $0.5 \%$ formaldehyde. The dye was then extracted from the intact and viable cells with a solution of 1\% acetic acid and 50\% ethanol. After an additional incubation in room temperature (15 $\mathrm{min}$ ) the absorbance (OD) values were measured by spectrophotometry at 540 $\mathrm{nm}$. Results were expressed as percentage of control.

\section{Statistical Analysis}

The results are expressed as mean \pm SEM. The differences in cell viability (mean MTT and neutral red assays) between groups were determined by one-way ANOVA, followed by 
the Newman-Keuls test. $p<0.05$ was considered significant.

\section{Results}

\section{GC-MS Analysis}

Identification of the compounds was based on a comparison of retention indices and mass spectra with those of authentic samples and with NIST MS library. The identification was also confirmed by comparison of the retention indices with data in the literature. The main components were carvacrol $(51.0 \%)$, thymol $(20.84 \%)$, boroneol $(6.80 \%)$, cymene $(6.25 \%)$, gama-terpinene $(5.50 \%)$ and beta myrcene (1.63 \%). Quantitative data were obtained from electronic integrative of FID area percentage without correction factors.

\section{The Effects of Thymus Caramanicus Essential Oil and Extract on Cell Viability}

At first, were analyzed the effects of different concentrations of the essential oil and extract on KB cell viability using the MTT assay. After $24 \mathrm{~h}$ attachment/ growth period, the cells were exposed to different concentration of essential oil $(0.05,0.25,0.5,1 \mu \mathrm{L} / \mathrm{ml})$ and extract $(25,50,75,100,150 \mu \mathrm{g} / \mathrm{mL})$ for a $24 \mathrm{~h}$ period. extract $(1 \quad B)$ could significantly decrease $K B$ cells cell viability. The calculated IC50 values for the essential oil and extract were $0.44 \mu \mathrm{L} / \mathrm{mL}$ and $105 \mu \mathrm{g} / \mathrm{mL}$ respectively. Surprisingly, KB cancer cells were more sensitive to the effective concentrations of Thymus caramanicus and their mortality rates were greater than those observed in HGF1-PI1 cells (Figs. $1 \mathrm{C}$ and $1 \mathrm{D}$ ).

For analysis of the lysosomal damage, the cells viability was assessed with neutral red assay. As shown in Figures $2 \mathrm{~A}$ and $2 \mathrm{~B}$, the essential oil $(\mathrm{IC} 50=0.35 \mu \mathrm{L} / \mathrm{mL})$ and extract (IC50 $=73.11 \mu \mathrm{g} / \mathrm{mL}$ ) induced a potent toxic effect on KB cells. Furthermore, Thymus caramanicus in effective concentration had more toxic effect on KB cells than on HGF1-PI1 (Figs. 2C and 2D).

\section{Combination Treatment}

For combination therapy, the effects of Thymus extract and essential oil were determined accompanied with doxorubicin, a common anticancer drug. Doxorubicin at concentrations of 2 and $3 \mu \mathrm{g} / \mathrm{mL}$ showed a mild toxic property. Therefore, those concentrations were used for combination therapy with sub-effective concentrations of Thymus caramanicus essential oil $(0.05 \mu \mathrm{L} / \mathrm{mL})$ and extract $(25 \mu \mathrm{g} / \mathrm{mL})$.

As shown in Figure 3, sub-effective concentrations of Thymus caramanicus essential oil (Figs. 3A and 3B) and extract (Figs. $3 \mathrm{C}$ and $3 \mathrm{D}$ ) significantly potentiated the effect of anticancer drug doxorubicin in 2 and $3 \mu \mathrm{g} / \mathrm{mL}$ concentrations.
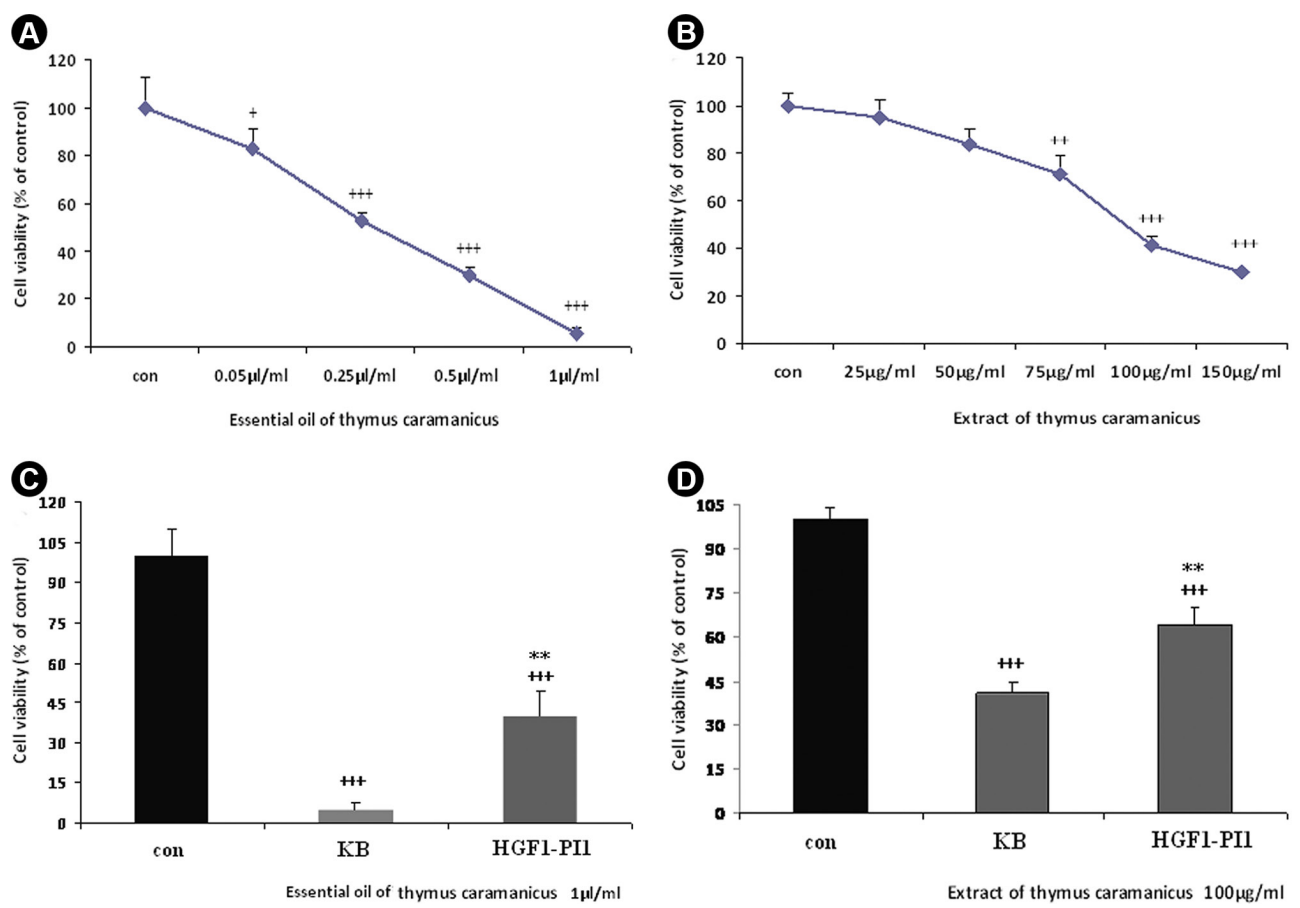

Figure 1. Effect of different concentrations of Thymus caramanicus essential oil (A) and its extract (B) on cancer KB cells viability, determined by MTT assay. Effective concentrations of Thymus caramanicus essential oil (C) and its extract (D) have more potent toxic effects on cancer KB cells than on HGF1-PI1 normal gingival cell viability. Data are expressed as mean \pm SEM; $n=5-6$ wells for each group; $+p<0.05,++p<0.01$ and $+++p<0.001$ versus control non-treated cells. ${ }^{* *} \mathrm{p}<0.01$ versus KB cells treated with effective concentrations of Thymus caramanicus. 


\section{Discussion}

Cancer is a very complex disease and the occurrence and development of tumor cells is closely related to abnormal intracellular signal transduction system (9). Because oral
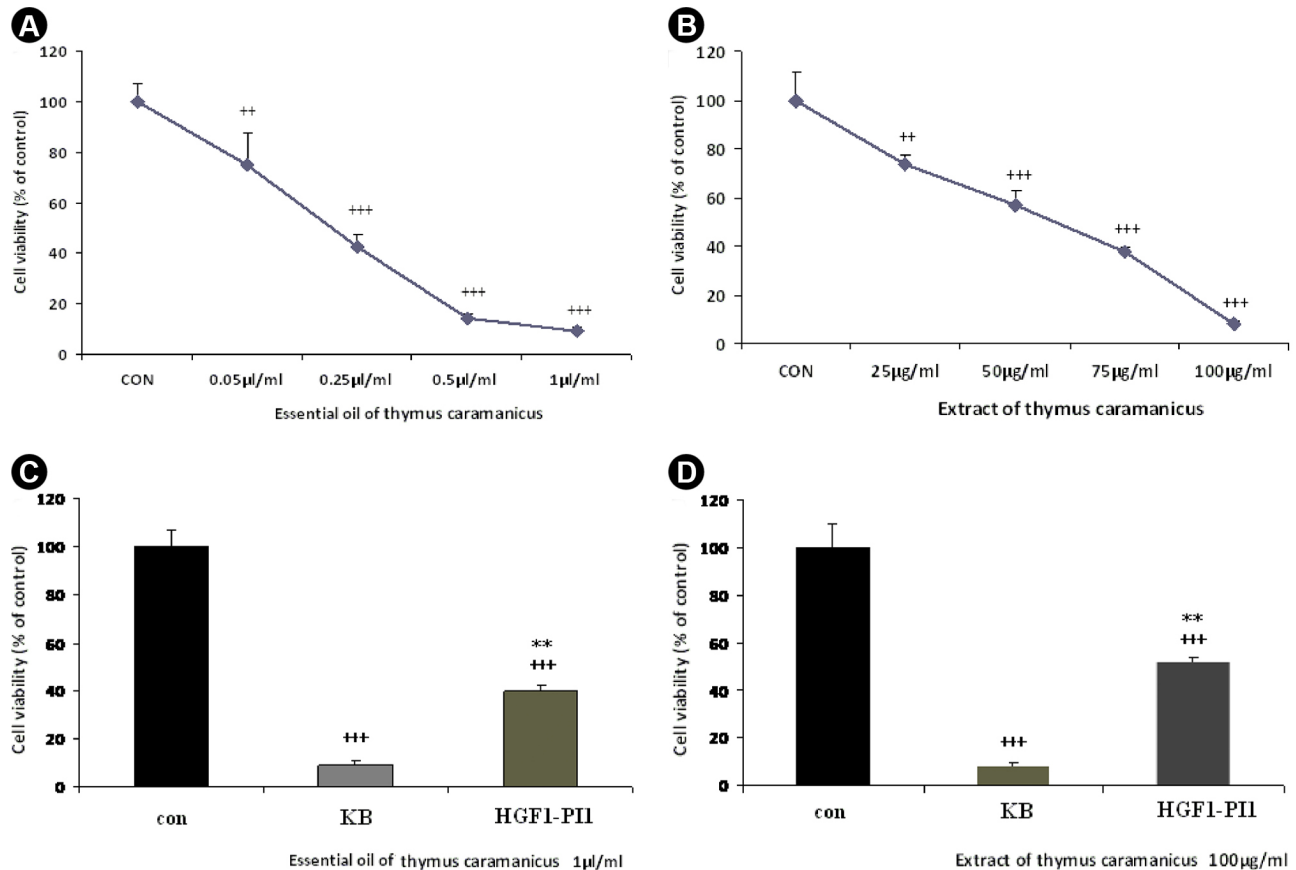

Figure 2. Effect of different concentrations of Thymus caramanicus essential oil (A) and its extract (B) on cancer KB cells viability determined by neutral red assay. Effective concentrations of Thymus caramanicus essential oil (C) and its extract (D) have more potent toxic effects on cancer KB cells than on HGF1-PI1 normal gingival cell viability. Data are expressed as mean \pm SEM; $n=5-6$ wells for each group; $+p<0.05,++p<0.01$ and $+++p<0.001$ versus control non-treated cells. ${ }^{* *} \mathrm{p}<0.01$ versus KB cells treated with effective concentrations of Thymus caramanicus.
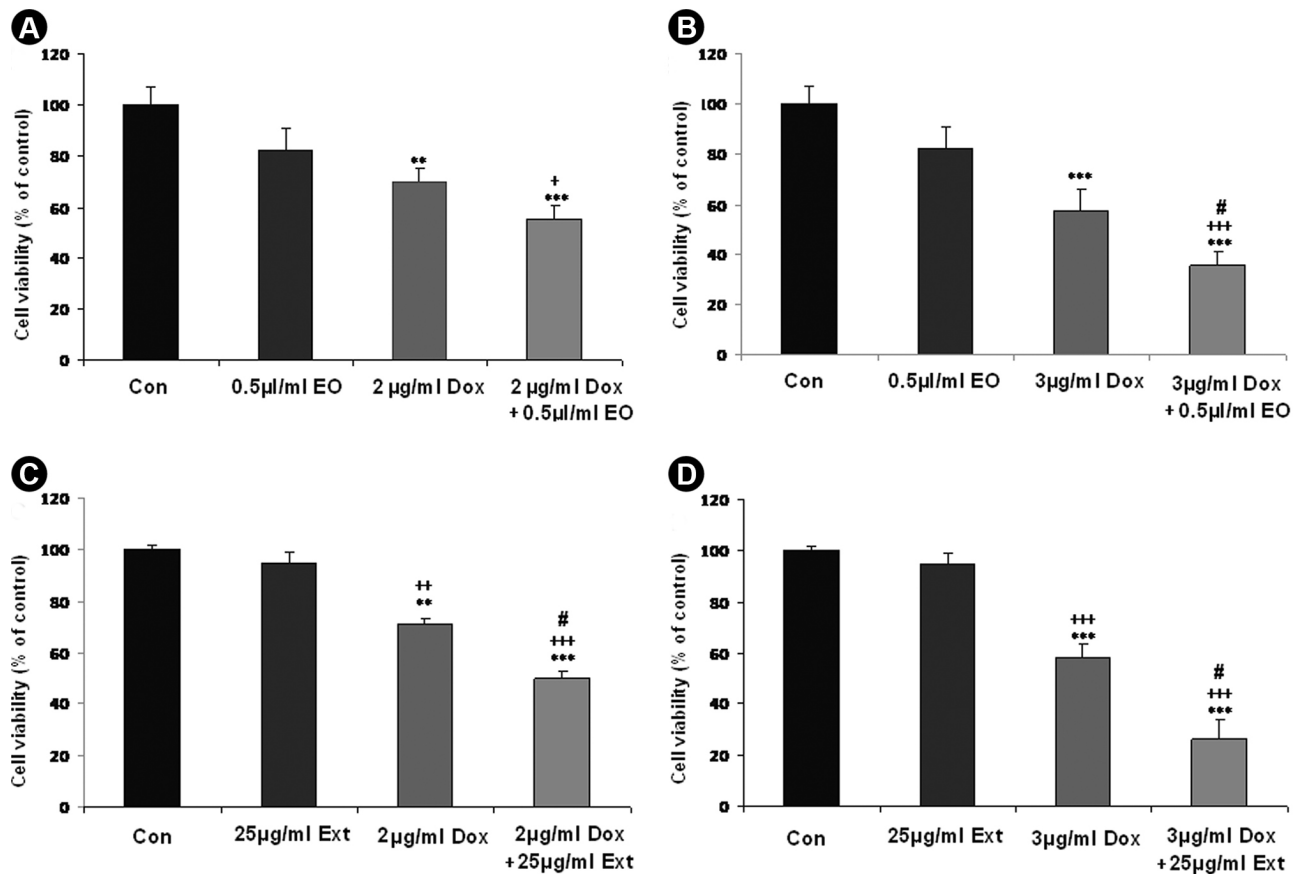

Figure 3. Effect of sub-effective concentration of Thymus caramanicus essential oil $(0.5 \mu \mathrm{l} / \mathrm{ml})$ in combination with 2 and $3 \mu \mathrm{g} / \mathrm{mL}$ doxorubicin on KB cell viability determined by MTT (A and B) and neutral red (C and D) assays. Data are expressed as mean \pm SEM; $n=5-6$ wells for each group; ${ }^{* *} \mathrm{p}<0.01,{ }^{* * *} \mathrm{p}<0.001$ versus control cells. $+\mathrm{p}<0.05,++\mathrm{p}<0.01$ and $+++\mathrm{p}<0.001$ versus $0.5 \mu \mathrm{L} / \mathrm{mL}$ essential oil or $25 \mu \mathrm{g} / \mathrm{mL}$ extract treated groups. \#p<0.05 versus doxorubicin treated cell. 
cancer is a type of highly malignant tumor with a potent capacity to invade locally and metastasize distantly an approach to decrease tumor's ability to invade and metastasize may facilitate the development of effective adjuvant therapy (10). Oral squamous cell carcinoma is highly resistant to conventional chemotherapy or radiation therapy and the current treatment strategy for carcinomas attempts to attack homogenous cancerous tissues thus the development of novel anticancer drugs is a simple method for remedy of cancer (11). The variability of clinical outcomes in oral cancer patients and the heterogeneity of the disease are the main challenges for the improvement of current treatment modalities (12).

Nowadays, one of the main methods of modern cancer treatment is chemotherapy (sometimes cancer chemotherapy). Most chemotherapeutic agents for cancer have different substantial short and long term unwanted side effects. Thus, in recent years major research has been focused on herbs and plants which have been considered for being nontoxic and for the prevention and treatment of certain types of cancer.

In the present study has shown that essential oil (1 $\mu \mathrm{L} / \mathrm{mL})$ and extract $(100 \mu \mathrm{g} / \mathrm{mL})$ of Thymus caramanicus normal cells.

Therefore, this plant may a candidate for further studies. Thymus caramanicus contains polyphenols responsible for its observed anticancer effect in this study. Thymol (20.846\%) and carvacrol (51.037\%) are the main components of Thymus caramanicus. The leaves and flowers of plants contain numerous aroma chemicals, which are widely used in folk medicine and in modern aromatherapies. Phenolic phytochemicals are thought to promote optimal health partly via their antioxidant and free radical scavenging effects, thereby protecting cellular components against free radical induced damages (13). Antioxidant properties of oil and volatile extracts from Thyme have been reported by different groups applying different methods (14). Natural antioxidants with their ability to scavenge free radicals might protect the cells from different diseases such as from cancer (15).

As well known, carvacrol has shown to exhibit antimicrobial, anti-mutagenic, anti-platelet, analgesic, anti-inflammatory, anti-angiogenic, antioxidant, antielastase, insecticidal, anti-parasitic, cell-protective, AChE (Acetylcholinesterase) inhibitor and anti-tumor activity (16). It has been revealed that carvacrol induces antiproliferative effect on non-small cell lung cancer, A549, chronic myeloid leukemia, K562, Hep-2, murine B16 melanoma and human metastatic MDA-MB231 breast cancer cells (17).

In addition, some findings suggested that the antitumor activity of carvacrol is not due to direct cytotoxicity but possibly by prevention of prenylation of several proteins including Ras (18). Reports state that its mechanism is due to its antioxidant nature (19). Recently, it has been demonstrated that the anti-proliferative effects of carvacrol in metastatic breast cancer cells (MDA-MB231) is based on the activation of the classical apoptosis response, including decrease in mitochondrial membrane potential and increase in cytochrome $\mathrm{c}$ release from mitochondria, decrease in $\mathrm{Bcl}-2 / \mathrm{Bax}$ ratio, increase in caspase activity and cleavage of PARP (poly(ADP-ribose) polymerase) and fragmentation of DNA, which belong to the mitochondrial pathway of the apoptosis (20).

The MAPK (Mitogen-activated protein kinases) pathway, especially JNK(c-Jun N-terminal kinases), ERK(extracellular signal-regulated kinase), and p38, has different functions in the apoptosis of various cancer cells (21). Previous research has shown that carvacrol effects involve ERK and the phosphorylation of p38 MAPK and JNK (22). Carvacrol can decrease the phosphorylation of ERK $1 / 2$ MAPK and activate phosphorylation of $\mathrm{p} 38$ MAPK but has no effect on JNK and MAPK in HepG2 cells, and their role in carvacrolinduced apoptosis is still unclear (23).

A common anticancer drug, doxorubicin, presents some problems because of its side effects. The dose-limiting side effect of doxorubicin is the development of acute and chronic cardiotoxicity leading to arrhythmia and congestive heart failure (24). Another impediment to successful chemotherapy with doxorubicin is the development of multidrug resistance (25). The cardiotoxic effects of doxorubicin have been demonstrated to be due to increased oxidative stress caused by free radical overproduction and reduction of endogenous antioxidant reserve (26)(25). For this reason, if doxorubicin is used in lower doses, its side effects are reduced. The present results showed that combination of doxorubicin with Thymus caramanicus could induce cell toxicity in oral carcinoma cells more than any of them alone. Thus, a plant like Thymus caramanicus with potent antioxidant activity may decrease doxorubicininduced side effects.

In this study Thymus caramanicus potentiated the effect of doxorubicin in KB cells. So, synchronized treatment of doxorubicin with Thymus caramanicus may be considered a strategy for decreasing doxorubicin doses and its side effect which routinely occur with high doxorubicin doses.

The conducted study indicates that essential oils and extracts of Thymus caramanicus have potential antiproliferative property on KB cells and may be used as pharmaceutical case study for oral cancer treatments. 
However, the exact molecular mechanism or mechanisms underlying anticancer effects of Thymus caramanicus need to be clarified in further research.

\section{Resumo}

A identificação de novos agentes quimioterápicos com menos efeitos colaterais é uma grande preocupação para os cientistas de hoje. Thymus caramanicus Jalas (familia Lamiaceae) é uma das espécies de Thymus que cresce selvagem em diferentes regiões do Irã. Tradicionalmente, as folhas desta planta são utilizados no tratamento da diabetes, artrite e câncer. Aqui investigamos a propriedade citotóxica do óleo essencial e extrato de Thymus caramanicus em células da linhagem celular tumoral humana de carcinoma epidermóide de boca (KB). A viabilidade celular foi medida por ensaios MTT e vermelho neutro. As células foram expostas a diferentes concentrações de óleo essencial $(0,05-1 \mu \mathrm{L} / \mathrm{mL})$ e extrato $(25-150 \mu \mathrm{g} / \mathrm{mL})$ durante $24 \mathrm{~h}$. A doxorrubicina foi utilizada como droga de controle anticâncer. Os dados mostraram que o óleo essencial (IC50 $=0,44 \mu \mathrm{L} / \mathrm{mL})$ e o extrato $(I C 50=105 \mu \mathrm{g} / \mathrm{mL})$ induzem uma potente propriedade citotóxica. Surpreendentemente, os efeitos citotóxicos de óleo essencial e extrato desta planta sobre células cancerígenas KB foram maiores que sobre a linhagem celular gengival normal HGF1-PI1. Além disso, Thymus caramanicus poderia potencializar o efeito da doxorrubicina em concentrações sub-efetivas. Os resultados do presente estudo indicam que óleos essenciais e extratos de Thymus caramanicus têm potenciais propriedades anti-proliferativas sobre células KB e podem ser usado como estudos de caso farmacêuticos para tratamentos de câncer bucal

\section{Acknowledgements}

This work was supported by funds from AJA University of Medical Science.

\section{References}

1. Kumar V, Sindhu VA, Rathanaswamy S, Jain J, Pogal JR, Akhtar N, et al.. Cancers of upper gingivobuccal sulcus, hard palate and maxilla: A tertiary care centre study in North India. Natl J Maxillofac Surg 2013;4:202-205.

2. Lyons $\mathrm{A}$, Jones J. Cell adhesion molecules, the extracellular matrix and oral squamous carcinoma. Int J Oral Maxillofac Surg 2007;36:671-679.

3. Gao N, Budhraja A, Cheng S, Yao H, Zhang Z, Shi X. Induction of apoptosis in human leukemia cells by grape seed extract occurs via activation of c-Jun NH2-terminal kinase. Clin Cancer Res 2009;15:140149.

4. Lee J-H, Hong S-M, Yun J-Y, Myoung H, Kim M-J. Anti-cancer effects of cordycepin on oral squamous cell carcinoma proliferation and apoptosis in vitro. J Cancer Ther 2011;2:224.

5. Fahey JW, Talalay $P$, Kensler TW. Notes from the field:"green" chemoprevention as frugal medicine. Cancer Prev Res (Phila) 2012;5:179-188.

6. Hudaib M, Speroni E, Di Pietra AM, Cavrini V. GC/MS evaluation of thyme (Thymus vulgaris $L$.) oil composition and variations during the vegetative cycle. J Pharm Biomed Anal 2002;29:691-700.

7. Bauer $K$, Garbe D, Surburg H. Common fragrance and flavor materials: preparation, properties and uses: John Wiley \&t Sons; 2008.

8. Nejad Ebrahimi S, Hadian J, Mirjalili M, Sonboli A, Yousefzadi M. Essential oil composition and antibacterial activity of Thymus caramanicus at different phenological stages. Food Chem 2008;110:927-931.

9. Wolf $B$, Brischwein $M$, Lob V, Ressler J, Wiest J. Cellular signaling: aspects for tumor diagnosis and therapy. Biomed Tech 2007:52:164-168.

10. Greenberg JS, El Naggar AK, Mo V, Roberts D, Myers JN. Disparity in pathologic and clinical lymph node staging in oral tongue carcinoma. Cancer 2003;98:508-515.

11. Moore $S$, Johnson N, Pierce A, Wilson D. The epidemiology of mouth cancer: a review of global incidence. Oral Dis 2000;6:65-74.

12. Ganly I, Morris L, Taylor B, Singh B, Viale A, Chan T. P124. Dysregulation of the PI3K/AKT/MTOR pathway by mutation and copy number alteration in oral cavity squamous cell cancer. Oral Oncol 47:S114.

13. Dapkevicius A, van Beek TA, Lelyveld GP, van Veldhuizen A, de Groot $A$, Linssen JP, et al.. Isolation and structure elucidation of radical scavengers from Thymus vulgaris leaves. J Nat Prod 2002;65:892-896.

14. Miura K, Kikuzaki $H_{1}$ Nakatani N. Antioxidant activity of chemical components from sage (Salvia officinalis L.) and thyme (Thymus vulgaris $L$.) measured by the oil stability index method. J Agric Food Chem 2002;50:1845-1851

15. Niture SK, Rao US, Srivenugopal KS. Chemopreventive strategies targeting the MGMT repair protein: augmented expression in human lymphocytes and tumor cells by ethanolic and aqueous extracts of several Indian medicinal plants. Int J Oncol 2006;29:1269-1278.

16. Baser KH. Biological and pharmacological activities of carvacrol and carvacrol bearing essential oils. Curr Pharm Des 2008;14:3106-3119.

17. Arunasree K. Anti-proliferative effects of carvacrol on a human metastatic breast cancer cell line, MDA-MB 231. Phytomedicine 2010;17:581-588.

18. Zeytinoglu H, Incesu Z, Baser K. Inhibition of DNA synthesis by carvacrol in mouse myoblast cells bearing a human N-RAS oncogene. Phytomedicine 2003;10:292-299.

19. Yoon $\mathrm{S}$, Seger R. The extracellular signal-regulated kinase: multiple substrates regulate diverse cellular functions. Growth factors 2006;24:21-44

20. Karkabounasli S, Metsios A, Lekkas P, Kotsis N, Skoufos I. Anticarcinogenic and antiplatelet effects of carvacrol. Exp Oncol 2006;28:121-125.

21. Ohsawa R, Miyazaki H, Niisato N, Shiozaki A, Iwasaki Y, Otsuji E, et al.. Intracellular chloride regulates cell proliferation through the activation of stress-activated protein kinases in MKN28 human gastric cancer cells. J Cell Physiol 2010;223:764-770.

22. Lee J, Jung E, Yu H, Kim Y, Ha J, Kim YS, et al.. Mechanisms of carvacrolinduced expression of type I collagen gene. J Dermatol Sci 2008;52:160169.

23. Yin Q-h, Yan F-x, Zu X-Y, Wu Y-h, Wu X-p, Liao M-c, et al.. Antiproliferative and pro-apoptotic effect of carvacrol on human hepatocellular carcinoma cell line HepG-2. Cytotechnology 2012;64:43-51

24. Minotti G, Recalcati S, Menna P, Salvatorelli E, Corna G, Cairo G. Doxorubicin cardiotoxicity and the control of iron metabolism: quinone-dependent and independent mechanisms. Methods Enzymol 2004:378:340-361.

25. van Asperen J, van Tellingen O, Beijnen JH. Determination of doxorubicin and metabolites in murine specimens by high-performance liquid chromatography. J Chromatogr B Biomed Sci Appl 1998;712:129143.

26. Singal $P$, Li T, Kumar D, Danelisen I, lliskovic N. Adriamycin-induced heart failure: mechanisms and modulation. Mol Cell Biochem. 2000;207:77-86. 